\title{
Editorial \\ Seed Science Research: Global Trends in Seed Biology and Technology
}

\author{
José Antonio Hernández Cortés (D)
}

Group of Fruit Biotechnology, Department of Fruit Breeding, CEBAS-CSIC, P.O. Box 164, 30100 Murcia, Spain; jahernan@cebas.csic.es

Citation: Hernández Cortés, J.A. Seed Science Research: Global Trends in Seed Biology and Technology. Seeds 2022, 1, 1-4. https://doi.org/ 10.3390/seeds1010001

Received: 22 September 2021 Accepted: 22 September 2021 Published: 9 October 2021

Publisher's Note: MDPI stays neutral with regard to jurisdictional claims in published maps and institutional affiliations.
Seeds are the central components of the plant life cycle because the establishment of a new generation of plants depends on them. Seeds are not only an indispensable source of food for the human diet but also for animals, providing significant contribution to the consumed calories [1,2].

Seed germination is a complex process. The success of seed germination and seedling establishment is crucial for spreading plant species and has great economic and ecological impact [3].

Germination sensu stricto includes events starting with water uptake by the quiescent dry seed and culminates with the elongation of the embryonic axis and the emergence of the radicle [4].

The germination process is linked to important changes in the redox state of the seeds, and a relationship between reactive oxygen species (ROS) and plant hormones in this process is well known. In that regard, a $\mathrm{H}_{2} \mathrm{O}_{2}$-dependent abscisic acid (ABA) decline has been documented in germinating seeds [5-8]. In addition, it has been reported that ROS can stimulate gibberellins (GA) biosynthesis $[7,8]$. Thus, ROS can favour the decline in the $\mathrm{ABA} / \mathrm{GAs}$ ratio during seed germination [6,7] in a similar fashion to that reported in the dormancy release in floral buds $[9,10]$.

ROSs, such as nitric oxide (NO), in addition to different nitrogen-containing compounds, including nitrite, nitrate and sodium nitroprusside (SNP, a NO-generating compound), have also been associated with seed dormancy breaking and the germination process $[4,11,12]$. Both $\mathrm{KNO}_{3}$ and sodium nitroprusside (SNP), a nitric oxide (NO)-donor, stimulated early seedling growth. Both treatments reduced ABA concentrations and induced the $\mathrm{GA}_{4}$ levels in pea seedlings, thus resulting in a strong decrease in the ABA/GA ratio [12].

Seed dormancy can be defined as the inability of a viable seed to germinate under optimal conditions [13]. The regulation of seed dormancy involves some plant hormones (ABA, GAs and ethylene) [5], some environmental factors [14] and several signaling molecules (NO and ROS) $[4,11]$. ABA abundance and signaling play a role in the seed dormancy process during seed development, whereas oxidation events also seem to regulate the depth of dormancy [15].

Therefore, both seed germination and seed dormancy are regulated by the interaction plant hormones/ROS metabolism, and antioxidant-related mechanisms seem to participate in the fine-tune control of ROS accumulation during both processes [5-7].

Developing strategies to increase the production of horticultural crops in a sustainable manner is an essential objective for researchers. Horticulturists face the challenge of producing more food in a situation of global population increase in a climate change context. Seed germination and seed vigor can be enhanced by treatments named as "seed priming". Thus, priming can be defined as a treatment or condition for enhancing seed quality. This strategy resulted in stimulation of germination that can also induce tolerance to environmental stress conditions and increase crop production [16]. Priming can be achieved by the addition of different chemicals during the imbibition process, 
including osmotic solutions (PEG, osmopriming); inorganic salts such as $\mathrm{NaCl}, \mathrm{KNO}_{3}$, $\mathrm{NaNO}_{3}$ and so on (halopriming); and disinfectant compounds (chemopriming, sodium hypochlorite $(\mathrm{NaOCl})$ and hydrochloric acid $(\mathrm{HCl}))$ [16], among others. In this group of chemical compounds, hydrogen peroxide $\left(\mathrm{H}_{2} \mathrm{O}_{2}\right)$ should also be included. At low concentrations, $\mathrm{H}_{2} \mathrm{O}_{2}$ stimulates seed germination and the early seedling growth of plants (Figure 1) $[5-7,17,18]$. The short treatments of seeds with red lights also stimulated seed germination and vigor [19] (Figure 2).

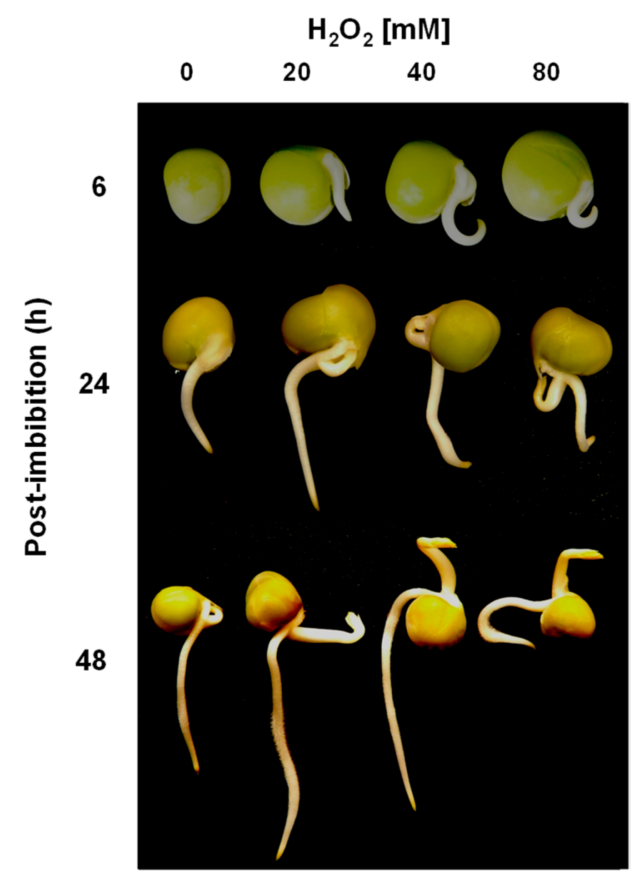

Figure 1. Effect of imbibition of pea and melon seeds in the presence of different $\mathrm{H}_{2} \mathrm{O}_{2}$ concentrations for $12 \mathrm{~h}$. Seeds were then washed with $\mathrm{dH}_{2} \mathrm{O}$ and placed in Petri dishes with $\mathrm{dH}_{2} \mathrm{O}$ and incubated in darkness up to $48 \mathrm{~h}$. Reprinted from Ref. [18].

\section{Time (min)}

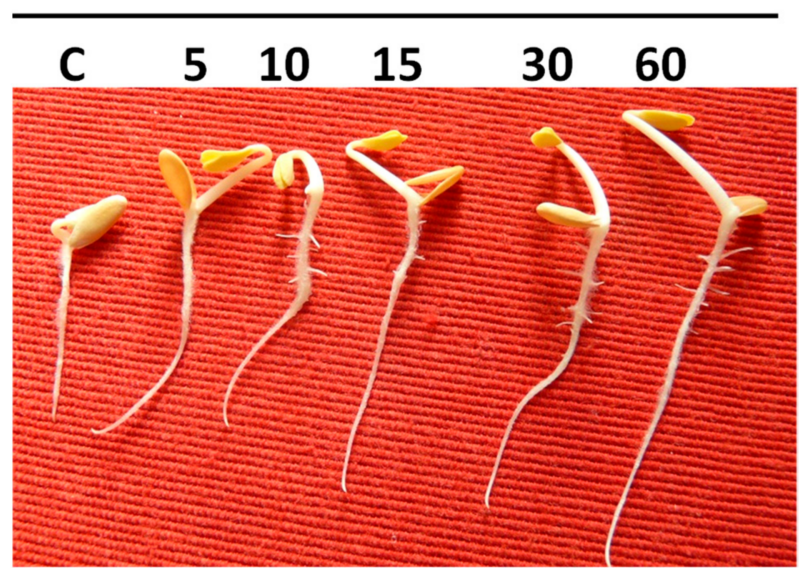

Figure 2. Effect of red-light exposure $\left(15 \mu \mathrm{mol} \mathrm{m} \mathrm{m}^{-2} \mathrm{~s}^{-1}\right.$ ) (up to $60 \mathrm{~min}$ ) of melon seeds on the germination rate and early seedling growth in 4 day old seedlings. Reprinted from Ref. [19].

These compounds can be a costless, effective and useful strategy for enhancing crop production and quality [20].

Seed priming induces a series of changes that improve the posterior response of the seedlings, including increases in $\mathrm{K}^{+}$content; prevention of chlorophyll degradation and 
increases in chlorophyll content; activation of antioxidant defenses; hormone metabolism modulation; proteome changes; and increases in yield and harvest quality [19]. Moreover, different priming techniques have proved to be effective in improving the nutritional value of the edible sprouts, resulting in greater health benefits [2].

I am confident that this new journal Seeds (ISSN: 2674-1024) [21] will contribute to elucidating the broad world of seed biology and technology. Therefore, I invite you to send us your research results and/or reviews related to the scope of this journal.

Conflicts of Interest: The author declares no conflict of interest.

\section{References}

1. Nambara, E.; Nonogaki, H. Seed biology in the 21st century: Perspectives and new directions. Plant. Cell Physiol. 2012, 53, 1-4. [CrossRef] [PubMed]

2. Aloo, S.O.; Ofosu, F.K.; Kilonzi, S.M.; Shabbir, U.; Oh, D.H. Edible plant sprouts: Health benefits, trends, and opportunities for novel exploration. Nutrients 2021, 13, 2882. [CrossRef] [PubMed]

3. Rajjou, L.; Duval, M.; Gallardo, K.; Catusse, J.; Bally, J.; Job, C.; Job, D. Seed germination and vigor. Annu. Rev. Plant. Biol. 2012, 63, 507-533. [CrossRef] [PubMed]

4. Diaz-Vivancos, P.; Barba-Espin, G.; Hernandez, J.A. Elucidating hormonal/ROSnetworks during seed germination: Insights and perspectives. Plant. Cell Rep. 2013, 32, 1491-1502. [CrossRef] [PubMed]

5. Liu, Y.; Ye, N.; Liu, R.; Chen, M.; Zhang, J. $\mathrm{H}_{2} \mathrm{O}_{2}$ mediates the regulation of ABA catabolism and GA biosynthesis in Arabidopsis seed dormancy and germination. J. Exp. Bot. 2010, 61, 2979-2990. [CrossRef] [PubMed]

6. Barba-Espín, G.; Nicolas, E.; Almansa, M.; Cantero-Navarro, E.; Albacete, A.; Hernández, J.A.; Díaz-Vivancos, P. Role of thioproline on seed germination: Interaction ROS-ABA and effects on antioxidative metabolism. Plant Physiol. Biochem. 2012, 59, 30-36. [CrossRef] [PubMed]

7. Bailly, C. The signalling role of ROS in the regulation of seed germination and dormancy. Biochem. J. 2019, 476, 3019-3032. [CrossRef] [PubMed]

8. Anand, A.; Kumari, A.; Thakur, M.; Koul, A. Hydrogen peroxide signaling integrates with phytohormones during the germination of magnetoprimed tomato seeds. Sci. Rep. 2019, 9, 8814. [CrossRef] [PubMed]

9. Hernandez, J.A.; Díaz-Vivancos, P.; Martínez-Sánchez, G.; Alburquerque, N.; Martínez, D.; Barba-Espín, G.; Acosta-Motos, J.R.; Carrera, E.; García-Bruntón, J. Physiological and biochemical characterization of bud dormancy: Evolution of carbohydrate and antioxidant metabolisms and hormonal profile in a low chill peach variety. Sci. Hortic. 2021, 281, 109957. [CrossRef]

10. Hernández, J.A.; Díaz-Vivancos, P.; Acosta-Motos, J.R.; Alburquerque, N.; Martínez, D.; Carrera, E.; García-Bruntón, J.; BarbaEspín, G. Interplay among antioxidant system, hormone profile and carbohydrate metabolism during bud dormancy breaking in a high-chill peach variety. Antioxidants 2021, 10, 560. [CrossRef] [PubMed]

11. Bethke, P.C.; Libourel, I.G.; Jones, R.L. Nitric oxide reduces seed dormancy in Arabidopsis. J. Exp. Bot. 2006, 57, 517-526. [CrossRef] [PubMed]

12. Vidal, A.; Cantabella, D.; Bernal-Vicentea, A.; Díaz-Vivancos, P.; Hernández, J.A. Nitrate- and nitric oxide-induced plant growth in pea seedlings is linked to antioxidative metabolism and the ABA/GA balance. J. Plant Physiol. 2018, 230, 13-20. [CrossRef] [PubMed]

13. Finch-Savage, W.E.; Leubner-Metzger, G. Seed dormancy and the control of germination. New Phytol. 2006, 171, 501-523. [CrossRef] [PubMed]

14. Holdsworth, M.J.; Bentsink, L.; Soppe, W.J.J. Molecular networks regulating Arabidopsis seed maturation, after-ripening, dormancy and germination. New Phytol. 2008, 179, 33-54. [CrossRef] [PubMed]

15. Chahtane, H.; Kim, W.; López-Molina, L. Primary seed dormancy: A temporally multilayered riddle waiting to be unlocked. J. Exp. Bot. 2017, 68, 857-869. [CrossRef] [PubMed]

16. Paparella, S.; Araujo, S.S.; Rossi, G.; Wijayasinghe, M.; Carbonera, D.; Balestrazzi, A. Seed priming: State of the art and new perspectives. Plant. Cell Rep. 2015, 34, 1281-1293. [CrossRef] [PubMed]

17. Barba-Espín, G.; Diaz-Vivancos, P.; Job, D.; Belghazi, M.; Job, C.; Hernández, J.A. Understanding the role of $\mathrm{H}_{2} \mathrm{O}_{2}$ during pea seed germination: A combined proteomic and hormone profiling approach. Plant. Cell Environ. 2011, 34, 1907-1919. [CrossRef] [PubMed]

18. Barba-Espín, G.; Hernández, J.A.; Diaz-Vivancos, P. Role of $\mathrm{H}_{2} \mathrm{O}_{2}$ in pea seed germination. Plant Signal. Behav. 2012, 7, 193-195.

19. Solano, C.J.; Hernández, J.A.; Suardiaz, J.; Barba-Espín, G. Impacts of LEDs in the red spectrum on the germination, early seedling growth and antioxidant metabolism of pea (Pisum sativum L.) and melon (Cucumis melo L.). Agriculture 2020, 10, 204. [CrossRef]

20. Zulfiqar, F. Effect of seed priming on horticultural crops. Sci. Hortic. 2021, 286, 110197. [CrossRef]

21. Seeds Home Page. Available online: https:/ / www.mdpi.com/journal/seeds (accessed on 22 September 2021). 
Short Biography of Author

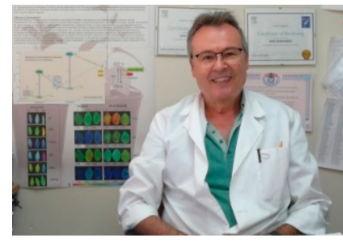

José Antonio Hernández Cortés is a doctor in Biology Sciences for the University of Murcia (Spain). Currently, he is a senior researcher at the CSIC. He is part of the Fruit Biotechnology Group at the institute of Edaphology and Applied Biology from the Segura (CEBAS-CSIC). I am an external professor of Plant Physiology at the Catholic University San Antonio from Murcia (UCAM). My research area includes plant physiology and biochemistry under environmental stress conditions and focuses on antioxidant metabolism. I have worked in seed biology, especially in the role of redox metabolism on seed germination, as well as the interrelation among hormones/redox state/carbohydrate metabolism in the dormancy release in flower buds from peach. By using $\left[{ }^{13} \mathrm{C}\right]$-labeled compounds, we provide strong evidence showing that cyanogenic glycosides (CNglcs) turnover is involved in SA biosynthesis in peach plants under control and stress conditions and mandelonitrile (MD) is the intermediary molecule controlling CNglcs turnover and SA biosynthesis. I have participated in 46 competitive $\mathrm{R}+\mathrm{D}+\mathrm{i}$ projects (national, regional, international and contracts with companies). I am the author of 115 SCI papers, with an h-index of 43 with almost 8000 citations (Web of Science). According to Google Scholar database, my h-index is 51, with a total of almost 13,000 citations. In addition to CEBAS, I have worked at L'Ecole Nationale Supérieure Agronomique de Toulouse (ENSAT, France) for more than 2 years and at the John Innes Center (Norwich, UK) for a period of 6 months. 